\title{
AKTIVITAS ANTIBAKTERI Staphyloccocos aureus dan Salmonella thypi EKSTRAK METANOL ANGGUR LAUT (Caulerpa racemosa)
}

\section{Antibacterial Activity Staphyloccocos aureus and Salmonella typhi Sea Grapes (Caulerpa racemosa) Methanol Extract}

\section{Sri Hainil ${ }^{*}$}

\section{Suci Fitriani Sammulia ${ }^{2}$}

Adella $^{3}$

\author{
1,2,3 Institut Kesehatan Mitra \\ Bunda, Batam, Kepulauan Riau, \\ Indonesia
}

*email:

Adellareffa04@gmail.com

\begin{abstract}
Abstrak
Anggur Laut merupakan salah satu jenis tumbuhan laut yang menghasilkan senyawa aktif yang berpotensi sebagai bahan obat yang berkhasiat sebagai antibakteri untuk menghambat pertumbuhan bakteri penyebab penyakit infeksi. Penelitian ini bertujuan untuk mengetahui aktivitas antibakteri Anggur laut yang berasal dari Kampung Terih, Pantai Nongsa Kepulauan Riau. Uji bakteri yang digunakan adalah Staphylococcos aureus dan Salmonella thypi. Pengujian aktivitas antibakteri menggunakan metode difusi kertas cakram dilakukan dengan mengukur zona hambat disekitar kertas cakram, dengan menggunakan varian konsentrasi $25 \%, 75 \%$, 100\%. Hasil penelitian menunjukkan bahwa ekstrak Anggur laut mampu menghambat pertumbuhan bakteri Staphylococcos aureus dengan terbentuk diameter rata-rata pada setiap konsentrasi $8,4 \mathrm{~mm}$ (daya hambat sedang); $9,1 \mathrm{~mm}$ (daya hambat sedang); 15,7 mm (daya hambat kuat). Bakteri Salmonella thypi membentuk diameter rata-rata pada setiap konsentrasinya $8,3 \mathrm{~mm}$ (daya hambat sedang); 9,3 $\mathrm{mm}$ (daya hambat sedang); 19,9 $\mathrm{mm}$ (daya hambat kuat). Ekstrak anggur laut memiliki potensi kuat dalam menghambat pertumbuhan bakteri.
\end{abstract}

Kata Kunci:

Anggur Laut

Antibakteri

Staphylococcos aureus

Salmonella thypi

Keywords:

Sea grapes

Antibacterial

Staphylococcos aureus

Salmonella typhi

\begin{abstract}
Sea Grape is one type of marine plant that produces active compounds that have the potential as medicinal ingredients that have antibacterial properties to inhibit the growth of bacteria that cause infectious diseases. This study aims to determine the antibacterial activity of sea grapes from Kampung Terih, Nongsa Beach, Riau Islands. The bacterial test used was Staphylococcos aureus and Salmonella typhi. Antibacterial activity testing using the disc paper diffusion method was carried out by measuring the inhibition zone around the disc paper, using a concentration variant of $25 \%, 75 \%, 100 \%$. The results showed that sea grape extract was able to inhibit the growth of Staphylococcos aureus bacteria by forming an average diameter at each concentration of $8.4 \mathrm{~mm}$ (medium inhibition); $9.1 \mathrm{~mm}$ (medium resistence); $15.7 \mathrm{~mm}$ (strong resistence); then Salmonella typhi bacteria formed an average diameter at each concentration of $8.3 \mathrm{~mm}$ (medium inhibition); $9.3 \mathrm{~mm}$ (medium inhibition); $19.9 \mathrm{~mm}$ (strong resistence). Sea grape extract has strong potential in inhibiting bacterial growth.
\end{abstract}

(C) year The Authors. Published by Institute for Research and Community Services Universitas Muhammadiyah Palangkaraya. This is Open Access article under the CC-BY-SA License (http://creativecommons.org/licenses/by-sa/4.0/). DOI: https://doi.org/10.33084/jsm.vxix.xxx.

\section{PENDAHULUAN}

Wilayah Indonesia di Provinsi Kepulauan Riau mempunyai pantai yang kaya akan sumber hayati yang melimpah khususnya hasil-hasil laut salah satunya yaitu anggur laut. Anggur laut mempunyai nama daerah yaitu Latoh (Jawa), Bulung Boni (Bali), dan Lawi-lawi (Sulawesi). Alga Caulerpa racemosa memiliki ciri-ciri thallus yang berwarna hijau seperti rumput laut, terdiri 
dari cabang tegak dan pada puncak terdapat bulatanbulatan seperti anggur (Yudasmara, 2014). Anggur laut dapat dimanfaatkan sebagai bahan makanan berupa lalapan dan pengobatan suatu penyakit salah satunya sebagai antibakteri.

Penyakit infeksi merupakan salah satu masalah kesehatan dengan jumlah yang cukup tinggi di Indonesia. Infeksi dapat disebabkan oleh virus, jamur, parasit, bakteri. Bakteri pantogen yang sering menyebabkan infeksi pada manusia salah satunya adalah Staphylococcus aureus dan Salmonella thypi (Perry \& Potter, 2014). Bakteri Staphylococcus aureus biasanya ditemukan di hidung, tenggorokan dan lapisan luar epidermis (Wulandari, 2017) dan Salmonella thypi merupakan bakteri yang terdapat pada usus manusia, yang masuk ke tubuh melalui makanan dan minuman yang tercemar dan dapat menyebabkan penyakit tifus (Candrawati, 20I0).

Penelitian yang dilakukan oleh (Marfuah, 2018) pada tahun 2018 tentang aktivitas antibakteri anggur laut Caulerpa racemosa didapatkan bahwa anggur laut mempunyai kandungan senyawa bioaktif antara lain alkaloid, flavonoid, fenol, tanin yang dapat berfungsi sebagai senyawa antibakteri. Senyawa antibakteri memiliki efektivitas dalam mengendalikan pertumbuhan bakteri khususnya bakteri yang merugikan manusia. Staphyloccocos aureus dan Salmonella thypi adalah bakteri yang biasa digunakan sebagai bakteri target dalam penelitian antibakteri. Kedua bakteri tersebut termasuk bakteri patogen yang menyebabkan penyakit. Oleh karena itu perlu adanya ekstrak bahan alami yang dapat digunakan sebagai antibakteri dalam menghambat dan membunuh bakteri patogen tersebut (Marfuah et al., 2018).

Telah banyak diteliti anggur laut (Caulerpa racemosa) sebagai aktivitas antibakteri pada bakteri Staphyloccocos aureus dan E.coli, tetapi belum ada ditemukan aktivitas antibakteri ekstrak anggur laut (Caulerpa racemosa) pada bakteri Staphyloccocos aureus dan Salmonella thypi khususnya di wilayah Kampung Terih pantai Nongsa Batam, Kepulauan Riau. Berdasarkan latar belakang tersebut maka dilakukan penelitian aktivitas antibakteri Staphyloccocos aureus dan Salmonella thypi ekstrak metanol anggur laut (Caulerpa racemosa) menggunakan metode difusi kertas cakram (disc diffusion method) dengan konsentrasi ekstrak 25\%, 75\%, 100\%.

\section{METODOLOGI}

\section{ALAT}

Alat yang digunakan antara lain autoklaf, erlenmeyer, hot plate (Maspion s.302), cawan petri, rotary evaporator (Heidolph made in Germany), timbangan digital (Kenko), vortex mixer, penyaring, tabung reaksi, rak tabung reaksi, oven, jarum ose, LAF (Laminar Air Flow) (magnehelic), bunsen, aluminium foil, magnetic stirrer, kertas saring, incubator (memmert), jangka sorong, mikroskop, kurs porselin, kertas cakram, kaca objek, cover gelas, batang pengaduk, wadah kaca, pinset, cotton steril, pipet mikro.

\section{BAHAN}

Bahan yang digunakan antara lain anggur laut (Caulerpa rasemosa), Nutrient Agar (NA) (HiMedia), metanol, $\mathrm{H}_{2} \mathrm{SO}_{4}$ (asam sulfat), $\mathrm{Na}_{2} \mathrm{C}_{3}$ (Natrium karbonat), serbuk Mg (Magnesium), pereaksi Mayer, $\mathrm{HCl}$ (asam klorida) pekat, aquadest, kloroform, chloralhidrat, $\mathrm{FeCl}_{3}$ (Besi III Klorida), $\mathrm{BaCl}_{2} \quad 1 \%$ (Barium Klorida), $\mathrm{CH}_{3} \mathrm{COOH}$ (asam asetat), aquadest steril, Kloramfenicol disc, bakteri gram positif Staphylococcus aureus, bakteri gram negatif Salmonella thypi, Alkohol 75\%, NaCL (Natrium klorida) $0,9 \%$.

\section{METODE}

\section{PENGAMBILAN SAMPEL}

Sampel yang akan digunakan pada penelitian ini adalah anggur laut (Caulerpa rasemosa) yang berada 
didaerah Kampung Terih Pantai Nongsa, Kepulauan Riau. Semua bagian tanaman anggur laut diambil sebanyak $18 \mathrm{~kg}$.

\section{PENYIAPAN SAMPEL}

Sampel anggur laut (Caulerpa rasemosa) yang telah terkumpul disortir dan dicuci bersih dibawah air mengalir agar terbebas dari lumpur, lalu anggur laut ditiriskan dan ditimbang berat awalnya. kemudian anggur laut di rajang kecil-kecil.

\section{PEMBUATAN EKSTRAK ANGGUR LAUT}

Anggur laut (Caulerpa rasemosa) sebanyak $18 \mathrm{~kg}$ di potong kecil-kecil, lalu dimasukkan kedalam wadah kaca dan dimaserasi menggunakan pelarut metanol hingga semua bagian anggur laut terendam. Maserasi dilakukan selama 3 hari, sambil diaduk setiap hari. Setiap 3 hari sekali filtrat disaring dan ampasnya di maserasi kembali dengan metanol. Proses maserasi dilakukan pengulangan sebanyak 3 kali.

Hasil maserat yang didapat dari ketiga maserasi digabungkan dan diuapkan pelarutnya menggunakan rotary evaporator hingga didapati ekstrak kental anggur laut. Rendemen yang diperoleh dihitung berdasarkan persentase bobot (b/b) dengan menggunakan persamaan berikut :

$\%$ Rendemen $\frac{\text { berat ekstrak kental yang didapat }}{\text { berat sampel yang digunakan }} \times 100 \%$

\section{KARAKTERISASI SIMPLISIA}

\section{a. Pemeriksaan Organoleptis}

Dilakukan identifikasi secara fisik dengan panca indera meliputi bau, bentuk dan warna dari simplisia (Febriyenti et al., 20/8).

\section{b. Pemeriksaan Mikroskopik}

Letakkan sedikit serbuk simplisia diatas kaca objek, lalu teteskan I tetes chloralhidrat dan tutup menggunakan cover glass. Amati menggunakan mikroskop dengan perbesaran hingga memperlihatkan penampang melintang simplisia.

c. Pemeriksaan Kemurnian
Amati simplisia bebas dari serangga, kotoran serangga dan kotoran lainnya, tidak adanya perubahan warna dan bau. Simpan simplisia dalam wadah kaca dan terlindung dari sinar matahari dan penyerapan (Depkes RI, 2000).

\section{KARAKTERISASI EKSTRAK}

a. Pemeriksaan Organoleptis

Dilakukan identifikasi secara fisik dengan panca indera meliputi bau, bentuk, dan warna dari ekstrak (Febriyenti et al., 2018).

b. Penetapan Susut Pengering

Timbang ekstrak kental sebanyak 2 gram lalu dimasukkan ke dalam krus porselin bertutup yang sebelumnya sudah dipanaskan pada suhu $105^{\circ} \mathrm{C}$ selama 30 menit dan telah di tara. Setelah itu krus porselin dimasukkan kedalam oven dalam keadaan tutup krus yang terbuka lalu dikeringkan pada suhu $105^{\circ} \mathrm{C}$ selama 30 menit, kemudian dikeluarkan dan didinginkan dalam desikator selama 15 menit dan ditimbang kembali. Lakukan pengulangan seperti cara yang diatas sampai diperoleh berat yang konstan (Depkes RI, 2000).

C. Penetapan Kadar Abu Total

Timbang ekstrak kental sebanyak 2 gram lalu dimasukkan kedalam krus porselin yang sebelumnya sudah dipanaskan pada suhu $105^{\circ} \mathrm{C}$ selama 30 menit dan telah ditara. Setelah itu krus porselin dimasukkan ke dalam furnace lalu dipijarkan pada suhu $600^{\circ} \mathrm{C}$ selama 7 jam, dikeluarkan dan didinginkan dalam desikator selama 15 menit dan timbang kembali (Febriyenti et al., 2018).

\section{d. Penetapan Kadar Air}

Dibersihkan cawan porselin dan dikeringkan dalam oven selama 15 menit pada suhu $105{ }^{\circ} \mathrm{C}$, kemudian didinginkan dalam desikator selama 30 menit dan ditimbang beratnya. Ditimbang sampel sebanyak 2 gram di letakkan dalam cawan porselin yang telah diketahui beratnya. Kemudian dikeringkan dalam oven pada suhu $100-105^{\circ} \mathrm{C}$ selama 3 jam, didinginkan di dalam desikator selama 15 menit lalu ditimbang. 
Perlakuan ini diulangi sampai tercapai lalu ditimbang. Perlakuan ini diulangi sampai tercapai berat konstan.

\section{SKRINING FITOKIMIA}

I. Uji Alkaloid (Harborne, 2006)

Diambil ekstrak anggur laut dimasukan kedalam tabung reaksi. Ditambahkan $5 \mathrm{ml}$ kloroform amoniak $0.05 \mathrm{~N}$, diaduk perlahan. Ditambahkan beberapa tetes $\mathrm{H}_{2} \mathrm{SO}_{4} \quad 2 \mathrm{~N}$. Dikocok perlahan hingga terjadi pemisahan. Diambil lapisan atas (asam) kedalam tabung reaksi. Ditambahkan sebanyak 2 tetes reagen Mayer. Jika positif terdapat alkaloid akan ditandai dengan terbentuknya endapan putih.

2. Uji Flavonoid (Harborne, 2006)

Diambil ekstrak anggur laut dimasukan kedalam tabung reaksi. Ditambahkan 2 tetes Asam Klorida pekat dan 0,I serbuk Magnesium lalu dikocok. Jika positif flavonoid akan ditandai dengan perubahan warna menjadi merah, kuning atau jingga.

3. Uji Fenolik

Diambil secuplik ekstrak simplisia dimasukan kedalam tabung reaksi. Ditambahkan 2 tetes $\mathrm{FeCl}_{3} 1 \%$. Jika positif fenolik akan ditandai dengan adanya perubahan warna menjadi biru tua atau hijau kehitaman.

4. Uji Saponin (Harborne, 2006)

Diambil ekstrak anggur laut dimasukan kedalam tabung reaksi. Ditambahkan beberapa tetes air panas, kemudian dikocok selama 5-15 menit. Diteteskan I tetes HCL 2N. Jika positif saponin akan ditandai dengan adanya busa permanen.

5. Uji Steroid/Triterpenoid (Harborne, 2006) Diambil seculik ekstrak simplisia ditambahkan 2-5 $\mathrm{ml}$ kloroform dan 10 tetes asam asetat anhidrat. Ditambahkan $\mathrm{H}_{2} \mathrm{SO}_{4}$ pekat melalui dinding tabung reaksi. Jika positif triterpenoid akan terbentuk cincin kecoklatan atau violet. Jika positif steroid akan terbentuk cincin biru kehijauan.

\section{STERILISASI}

Alat-alat yang akan digunakan dicuci bersih kemudian dikeringkan dan disterilkan terlebih dahulu. Lapisi semua alat-alat menggunakan aluminium foil dan sterilkan menggunakan autoklaf pada suhu $121^{\circ} \mathrm{C}$ selama 15 menit atau oven dengan suhu $170^{\circ} \mathrm{C}$ selama I jam. Alat-alat yang terbuat dari karet disterilkan dengan cara direndam dengan alkohol $70 \%$. Jarum ose disterilkan dengan dipijarkan menggunakan nyala bunsen. Laminar Air Flow (LAF) disterilkan dengan lampu UV selama 15 menit dan disemprotkan dengan alkohol 70\%. Sterilisasi Laminar Air Flow ini dilakukan sebelum dan sesudah bekerja didalamnya (Hainil et al., 202I).

\section{PEMBUATAN MEDIA NUTRIENT AGAR}

Pembuatan media agar dilakukan dengan cara 6 gram nutrient agar dilarutkan ke dalam $200 \mathrm{ml}$ aquadest ke dalam erlenmeyer. Kemudian campuran tersebut dipanaskan di atas hot plate agar homogen sampai mendidih selama \pm 40 menit. Media agar disterilkan ke dalam autoklaf pada suhu $121^{\circ} \mathrm{C}$ selama 15 menit. Setelah disterilisasi, media lalu didinginkan hingga suhunya mencapai $45^{\circ} \mathrm{C}$, baru kemudian dituangkan masing-masing sebanyak $20 \mathrm{ml}$ ke dalam cawan petri. Media Nutrient Agar (NA) yang telah dituang ke dalam cawan petri dibiarkan hingga mengeras (Retnaningsih et al., 2019).

\section{PEREMAJAAN BAKTERI}

Sebelum dilakukan uji antibakteri, bakteri yang akan digunakan harus diregenerasikan terlebih dahulu. Hal yang pertama kali harus dilakukan adalah membuat biakan agar miring, yaitu dengan menggoreskan biakan satu ose dari bakteri Staphylococcus aureus dan Salmonella typhi masing-masing pada agar miring yang masih baru kemudian diinokulasi pada suhu $37^{\circ} \mathrm{C}$ selama 24 jam didalam inkubasi.

\section{PEMBUATAN STANDAR MC FARLAND}

Masukkan larutan $\mathrm{BaCl}_{2} \cdot 2 \mathrm{H}_{2} \mathrm{O}$ I,75\% sebanyak 0,05 $\mathrm{mL}$ dan dicampurkan dengan larutan $\mathrm{H}_{2} \mathrm{SO}_{4}$ sebanyak 
9,95 mL ke dalam tabung reaksi, kemudian dikocok sampai terbentuk larutan keruh. Larutan ini digunakan sebagai standar kekeruhan bakteri uji (Abu bakar dan Yamlean, 2019).

\section{PEMBUATAN SUSPENSI BAKTERI}

Biakan bakteri yang telah berumur 24 jam diambil dari agar miring sebanyak 2 ose, koloni bakteri uji disuspensikan kedalam $10 \mathrm{ml} \mathrm{NaCl} \mathrm{0,9 \%} \mathrm{steril} \mathrm{dalam}$ tabung reaksi steril. Kemudian dihomogenkan dengan vortex. Kekeruhan dibandingkan dengan Mc Farland (Muljono et al., 2016).

\section{PEMBUATAN KONSENTRASI EKSTRAK METANOL ANGGUR LAUT}

Pada penelitian ini menggunakan tiga macam konsentrasi yaitu konsentrasi ekstrak 25\%, 75\% dan $100 \%$. Masing-masing dilakukan sebanyak tiga kali pengulangan. Konsentrasi ekstrak dibuat dalam $2 \mathrm{ml}$ aquadest. Kontrol positif yang digunakan yaitu Kloramfenicol disk dan kontrol negatifnya yaitu aquadest steril $10 \mathrm{ml}$.

\section{UI AKTIVITAS ANTIBAKTERI}

Pengujian aktivitas antibakteri dilakukan dengan metode (disc diffusion) menggunakan kertas cakram. Konsentrasi ekstrak yang digunakan 25\%, 50\%, dan 75\%. Kontrol positif kloramfenicol disk dan kontrol negatif aquadest. Menggunakan 6 cawan petri dengan lima perlakuan dan tiga kali pengulangan. Cawan petri yang telah disterilkan, dipanaskan dipinggirannya menggunakan api bunsen. Kemudian tuang sebanyak $20 \mathrm{ml}$ Nutrient Agar (NA) dimasukkan kedalam masing- masing cawan petri dan tambahkan suspensi bakteri sebanyak $50 \mu \mathrm{L}$ menggunakan mikropipet kemudian dioleskan menggunakan cotton steril media tersebut sampai memenuhi semua permukaan media. Dibiarkan I-5 menit agar suspensi masuk kedalam media agar. Selanjutnya dipipet sebanyak $10 \mu \mathrm{L}$ menggunakan mikropipet pada kertas cakram suspensi masuk kedalam media agar. Selanjutnya dipipet sebanyak $10 \mu \mathrm{L}$ menggunakan mikropipet pada kertas cakram, masing-masing larutan dengan konsentrasi ekstrak anggur laut 25\%, 75\%, $100 \%$. Kemudian tempelkan kertas cakram di atas permukaan nutrient agar. Kontrol positif menggunakan kloramfenicol disc dan kontrol negatif menggunakan aquadest steril. Lakukan pengulang sebanyak 3 kali. Kemudian cawan petri diinkubasi dalam inkubator selama I × 24 jam pada suhu $37^{\circ} \mathrm{C}$. Kemudian aktivitas antibakteri ditetapkan dengan mengukur diameter zona bening yang terbentuk menggunakan jangka sorong (Misna \& Diana, 2016).

\section{ANALISA DATA}

Analisis data dalam penelitian ini adalah menggunakan data deskriptif dengan penyajian data dan juga dalam bentuk tabel dengan melakukan pengamatan terhadap pengukuran diameter zona hambat dari daerah bening dari ekstrak pekat anggur laut.

\section{HASIL DAN PEMBAHASAN}

\section{Ekstraksi}

Penelitian ini menggunakan dengan metode maserasi, metode maserasi merupakan metode ekstraksi cara dingin dan merupakan metode yang sangat sederhana. Metode maserasi merupakan proses pengekstrakan simplisia menggunakan pelarut dengan beberapa kali pengadukan (Depkes ,2000).

Pelarut yang digunakan pada metode maserasi ini adalah metanol, karena metanol bersifat universal yang dapat menarik senyawa polar, dan non polar yang mudah menguap. Menurut Savitri et al, 2017 metanol merupakan pelarut terbaik untuk mengekstrak senyawa yang cenderung polar. Proses Contoh: maserasi dilakukan pengulangan sebanyak 3 kali. Hasil maserat yang didapat dari ketiga maserasi digabungkan dan hingga didapati ekstrak kental anggur laut menggunakan rotary evaporator. Maka didapatkan hasil rendemen sampel sebagai berikut :

Berat sampel : 
- Berat sampel awal anggur laut yang diperoleh : $18 \mathrm{~kg}=$ $18.000 \mathrm{~g}$

- Berat ekstrak kental metanol : 322 gram

$\%$ Rendemen $=\frac{\text { berat ekstrak kental yang didapat }}{\text { berat sampel yang digunakan }} \times 100 \%$

$$
\begin{aligned}
& =\frac{322 \mathrm{gram}}{18.000 \mathrm{gram}} \times 100 \% \\
& =1,78 \%
\end{aligned}
$$

\section{Karakterisasi simplisia dan ekstrak}

Karakterisai simplisia dan ekstrak merupakan suatu proses awalan yang dilakukan untuk mengetahui mutu dari suatu simplisia dan ekstrak (Depkes RI, 2000). Karakterisasi simplisia yang dilakukan pada penelitian ini berupa uji organoleptis yang menunjukkan bentuk serbuk dengan warna hijau, bau sedikit amis, rasanya asin (gambar I) dan penetapan kadar air menunjukkan hasil sebanyak II,5\% pada tabel I.

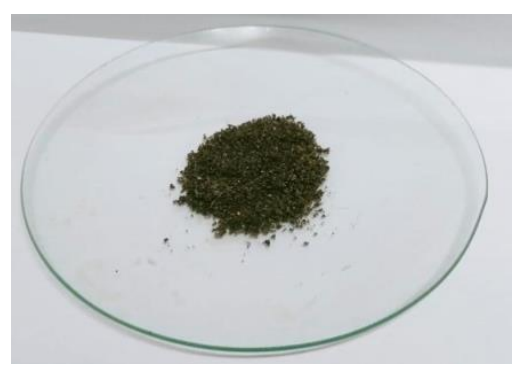

Gambar I. Pemeriksaan organoleptis

Tabel I. Hasil Kadar Air

\begin{tabular}{|c|c|c|c|c|c|}
\hline \multirow{2}{*}{$\begin{array}{c}\text { Berat Krus Kosong } \\
\text { (A) }\end{array}$} & $\begin{array}{c}\text { Berat Krus + Ekstrak } \\
\text { Sebelum di Oven (B) }\end{array}$ & \multicolumn{3}{|c|}{$\begin{array}{c}\text { Berat Krus + Ekstrak Setelah } \\
\text { di Oven (C) }\end{array}$} & \multirow{2}{*}{ \% Kadar Air } \\
\cline { 3 - 5 } & & $\begin{array}{c}\text { Oven Ke } \\
\text { I Oven Ke }\end{array}$ & $\begin{array}{c}\text { Oven Ke } \\
\mathbf{2}\end{array}$ & $\mathbf{3}$ & \\
\hline $30,425 \mathrm{~g}$ & $32,425 \mathrm{~g}$ & $32,200 \mathrm{~g}$ & $32,195 \mathrm{~g}$ & $32,195 \mathrm{~g}$ & $\mathrm{II}, 5 \%$ \\
\hline
\end{tabular}

Karakterisasi ekstrak yang dilakukan penelitian ini berupa uji organoleptis menunjukkan hasil bentuk ekstrak kental yang didapatkan berwarna hijau kehitaman, rasa asin, dan bau asam (gambar 2) dan Uji penetapan kadar abu total menunjukkan hasil 63,80\%. Pada tabel 2.

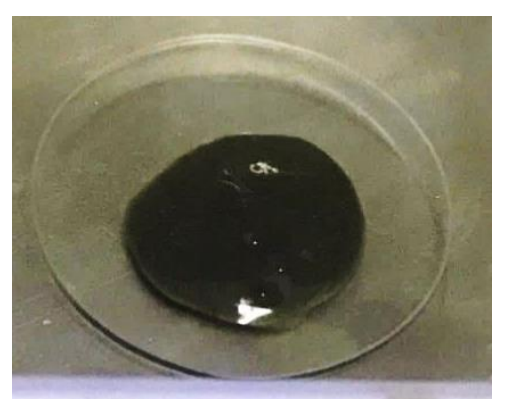

Gambar 2. Pemeriksaan organoleptis Ekstrak

Tabel 2. Penetuan Kadar Abu Ekstrak Skrining Fitokimia

\begin{tabular}{|c|c|c|c|c|c|}
\hline \multirow{2}{*}{$\begin{array}{c}\text { Berat Krus Kosong } \\
\text { (A) }\end{array}$} & $\begin{array}{c}\text { Berat Krus + Ekstrak } \\
\text { Sebelum di Oven (B) }\end{array}$ & \multicolumn{3}{|c|}{$\begin{array}{c}\text { Berat Krus + Ekstrak Setelah } \\
\text { di Oven (C) }\end{array}$} & \multirow{2}{*}{ \% Kadar Abu } \\
\cline { 3 - 5 } & & $\begin{array}{c}\text { Oven Ke } \\
\text { I }\end{array}$ & $\begin{array}{c}\text { Oven Ke } \\
\mathbf{2}\end{array}$ & $\begin{array}{c}\text { Oven Ke } \\
\mathbf{3}\end{array}$ & \\
\hline $53,400 \mathrm{~g}$ & $55,380 \mathrm{~g}$ & $54,515 \mathrm{~g}$ & $54,600 \mathrm{~g}$ & $54,600 \mathrm{~g}$ & $60,6 \%$ \\
\hline
\end{tabular}

Uji skrining fitokimia dilakukan untuk memberikan gambaran terhadap golongan zat senyawa yang terkandung didalam sampel yang diteliti. Uji skrining fitokimia dilakukan dengan pengujian warna menggunakan suatu pereaksi warna (Kristiani et al., 2008).

Hasil skrining fitokimia menunjukkan hasil positif pada senyawa metabolit sekunder alkaloid, flavonoid, 
fenolik, dan menunjukkan hasil negatif pada senyawa metabolit sekunder saponin dan steroid. Hal ini selaras dengan penelitian menurut (Marfuah et al., 20I8) yang menunjukkan hasil positif pada senyawa metabolit sekunder alkaloid, flavonoid, fenolik dan hasil negatif pada senyawa metabolit sekunder saponin dan steroid.

Berdasarkan hasil yang diperoleh, senyawa alkaloid berperan sebagai senyawa antibakteri. Pada Caulerpin, family Caulerpaceae spesies Caulerpa racemosa menghasilkan metabolit sekunder yaitu senyawa alkaloid bisindole, senyawa bisindole laut ditemukan senyawa bioaktif yang kuat berberapa diantaranya termasuk antijamur, antibakteri, antivirus, sitotoksik dan anti-inflamasi (Liu, 20I3)

Senyawa flavonoid berpotensi sebagai antibakteri menurut pendapat (Pendit et al., 2016) menyatakan bahwa mekanisme flavonoid sebagai antibakteri dengan cara menghambat sintesis asam nukleat, menghambat fungsi membran sel.

Senyawa bioaktif fenolik berperan sebagai antibakteri menurut (Purwantiningsih et al., 2014) menyatakan bahwa kandungan fenol dapat menembus dan mengganggu dinding sel bakteri.

\section{PEMBUATAN LARUTAN U}

Menggunakan tiga macam konsentrasi yaitu konsentrasi ekstrak 25\%, 75\% dan 100\%. Masingmasing dilakukan sebanyak tiga kali pengulangan. Konsentrasi ekstrak dibuat dalam $2 \mathrm{ml}$ aquadest. Pembuatan konsentrasi ekstrak dengan rumus
$\%$ konsentrasi $=\frac{m}{v} \times 100 \%$

Keterangan :

$\%$ konsentrasi $=$ konsentrasi ekstrak yang terdapat dalam pelarut

$\mathrm{m} \quad$ = berat/ massa dari ekstrak (gram)

$\checkmark \quad=$ jumlah total antara ekstrak dan

pelarut setelah ditambahkan pelarut $(\mathrm{ml})$

- Konsentrasi $25 \%$

Timbang ekstrak kental anggur laut 0,5 gram dan dilarutkan dalam $2 \mathrm{ml}$ aquadest dan aduk hingga homogen menggunakan vortex mixer.

- Konsentrasi $75 \%$

Timbang ekstrak kental anggur laut I,5 gram dan dilarutkan dalam $2 \mathrm{ml}$ aquadest dan aduk hingga homogen menggunakan vortex mixer.

- Konsentrasi $100 \%$ ekstrak kental murni.

Timbang ekstrak kental anggur laut 2 gram.

\section{PEMBUATAN SUSPENSI BAKTERI}

Biakan bakteri yang telah berumur 24 jam diambil dari agar miring sebanyak 2 ose, koloni bakteri uji

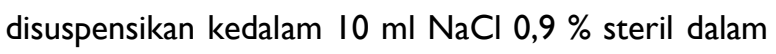
tabung reaksi steril. Kemudian dihomogenkan dengan vortex. Kekeruhan dibandingkan dengan Mc.Farland (Muljono et al., 2016).

\section{PEMBUATAN STANDAR MC.FARLAND}

Masukkan larutan $\mathrm{BaCl}_{2} \cdot 2 \mathrm{H}_{2} \mathrm{O}$ I,75\% sebanyak 0,05 $\mathrm{mL}$ dan dicampurkan dengan larutan $\mathrm{H}_{2} \mathrm{SO}_{4}$ sebanyak 9,95 $\mathrm{mL}$ ke dalam tabung reaksi, kemudian dikocok sampai terbentuk larutan keruh. Larutan ini digunakan sebagai standar kekeruhan bakteri uji (Abu bakar dan Yamlean, 2019).

\section{KONTROL POSITIF DAN KONTROL NEGATIF}


Pemilihan antibiotik kloramfenicol sebagai kontrol positif pada penelitian ini dikarenakan kloramfenicol merupakan antibiotik dengan sprektrum luas yang dapat menghambat pertumbuhan bakteri, bahkan mematikan bakteri gram positif dan gram negatif (Muharni et al., 2017). Aquadest sebagai kontrol negatif dan juga digunakan sebagai pelarut tidak memiliki aktivitas antibakteri terhadap bakteri uji dan juga dapat melarutkan ekstrak yang bersifat garam. Hasil uji kontrol positif dan kontrol negatif terhadap bakteri Staphyloccocos aureus tabel 3 dan Salmonella thypi tersaji pada tabel 4.

Tabel 3. Hasil Pengukuran Daya Hambat Bakteri Staphylococcos aureus

\begin{tabular}{|l|c|c|c|c|}
\hline $\begin{array}{c}\text { Kontrol } \\
(+) \\
\text { (kloramfenicol) }\end{array}$ & $33,6 \mathrm{~mm}$ & $33,6 \mathrm{~mm}$ & $33,6 \mathrm{~mm}$ & $33,6 \mathrm{~mm}$ \\
\hline $\begin{array}{c}\text { Kontrol } \\
(-) \\
\text { (aquadest steri }\end{array}$ & - & - & - & - \\
\hline
\end{tabular}

Tabel 4. Hasil Pengukuran Daya Hambat Bakteri

\begin{tabular}{|l|l|l|l|l|}
\hline $\begin{array}{c}\text { Kontrol } \\
(+) \\
(\text { kloramfenicol) }\end{array}$ & $33,7 \mathrm{~mm}$ & $33,7 \mathrm{~mm}$ & $33,7 \mathrm{~mm}$ & $33,7 \mathrm{~mm}$ \\
\hline $\begin{array}{c}\text { Kontrol } \\
(-) \\
\text { (aquadest steril) }\end{array}$ & - & - & - & - \\
\hline
\end{tabular}

\section{UJI ZONA HAMBAT}

Metode yang digunakan dalam uji aktivitas antibakteri yaitu metode difusi kertas cakram (disc diffusion method). Alasan penggunaan metode ini karena pengerjaannya sederhana, efisien dan praktis tidak ada alat khusus dalam pengerjaannya (Katrin et al., 20I5). Metode difusi cakram (disc diffusion method) dilakukan menggunakan kertas cakram yang sebelumnya sudah ditetesi pada larutan uji sampai seluruh permukaannya basah, kertas cakram diletakkan diatas media cawan yang telah dioleskan dengan bakteri. Lalu pengamatannya dilakukan setelah bakteri diinkubator selama I x 24 jam dengan suhu $37^{\circ} \mathrm{C}$. Pengujian aktivitas antibakteri ini bertujuan untuk mengetahui kemampuan dari ekstrak dalam menghambat bakteri yang akan diuji (Mayefis et al., 2020).

Hasil pengukuran Aktivitas Antibakteri ekstrak metanol Anggur Laut (Caulerpa racemosa) terhadap bakteri Staphylococcus aureus pada konsentrasi 25\% diperoleh diameter rata-rata daya hambat sebesar 8,4 mm (kategori daya hambat sedang), pada konsentrasi 75\% diperoleh diameter rata-rata daya hambat sebesar 9,I mm (kategori daya hambat sedang), pada konsentrasi $100 \%$ diperoleh diameter rata-rata daya hambat sebesar 15,7 mm (kategori daya hambat kuat), sedangkan kontrol positif diperoleh diameter rata-rata daya hambat sebesar 33,6 mm (kategori daya hambat sangat kuat) dan kontrol negatif $0 \mathrm{~mm}$ pada tabel $\mathbf{5}$ dan Salmonella thypi tabel 6.

Tabel 5. Hasil Respon Hambatan Pertumbuhan Antibakteri Staphylococcos aureus.

\begin{tabular}{|l|c|c|}
\hline Perlakuan & $\begin{array}{l}\text { Rata-rata } \\
\text { Diameter Zona } \\
\text { Hambat }(\mathrm{mm})\end{array}$ & $\begin{array}{l}\text { Respon } \\
\text { Hambatan } \\
\text { Pertumbuhan }\end{array}$ \\
\hline Konsentrasi $25 \%$ & $8,4 \mathrm{~mm}$ & Sedang \\
\hline Konsentrasi $75 \%$ & $9,1 \mathrm{~mm}$ & Sedang \\
\hline Konsentrasi $100 \%$ & $15,7 \mathrm{~mm}$ & Kuat \\
\hline $\begin{array}{l}\text { Kontrol + } \\
\text { (kloramfenicol) }\end{array}$ & $33,6 \mathrm{~mm}$ & Sangat Kuat \\
\hline $\begin{array}{l}\text { Kontrol (-) } \\
\text { (aquadest steril) }\end{array}$ & - & - \\
\hline
\end{tabular}




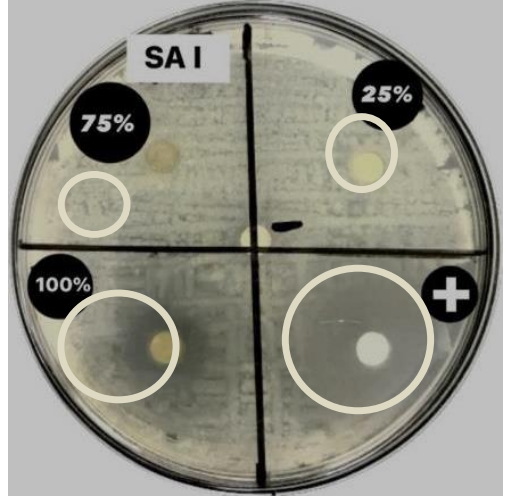

Gambar 3. Hasil Pengujian Pada Bakteri Staphylococcos aureus

Hasil pengukuran aktivitas antibakteri ekstrak metanol Anggur Laut (Caulerpa racemosa) terhadap bakteri Salmonella thypi pada konsentrasi 25\% diperoleh diameter rata-rata daya hambat sebesar $8,3 \mathrm{~mm}$ (kategori daya hambat sedang), pada konsentrasi 75\% diperoleh diameter rata-rata daya hambat sebesar 9,3 $\mathrm{mm}$ (kategori daya hambat sedang), pada konsentrasi $100 \%$ diperoleh diameter rata-rata daya hambat sebesar 19,9 mm (kategori daya hambat kuat), sedangkan kontrol positif diperoleh diameter rata-rata daya hambat sebesar 33,7 mm (kategori daya hambat sangat kuat) dan kontrol negatif $0 \mathrm{~mm}$.

Tabel 6. Hasil Respon Hambatan Pertumbuhan Antibakteri Salmonella thypi.

\begin{tabular}{|l|c|c|}
\hline Perlakuan & $\begin{array}{l}\text { Rata-rata } \\
\text { Diameter Zona } \\
\text { Hambat }(\mathrm{mm})\end{array}$ & $\begin{array}{l}\text { Respon } \\
\text { Hambatan } \\
\text { Pertumbuhan }\end{array}$ \\
\hline Konsentrasi 25\% & $8,3 \mathrm{~mm}$ & Sedang \\
\hline Konsentrasi 75\% & $9,3 \mathrm{~mm}$ & Sedang \\
\hline Konsentrasi $100 \%$ & $19,9 \mathrm{~mm}$ & $\begin{array}{c}\text { Kuat } \\
\text { Kangat } \\
\text { (kloramfenicol) }\end{array}$ \\
\hline $\begin{array}{l}\text { Kontrol (-) } \\
\text { (aquadest steril) }\end{array}$ & $33,7 \mathrm{~mm}$ \\
\hline
\end{tabular}

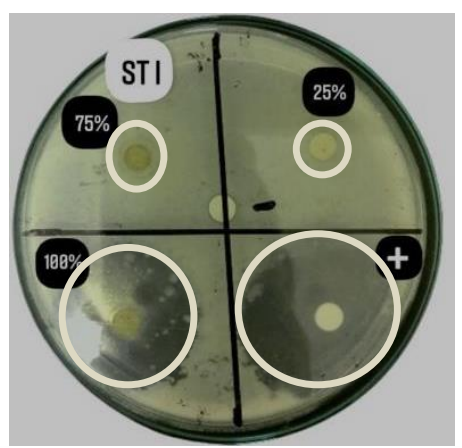

GAMBAR 4. Hasil Pengujian Pada Bakteri Salmonella thypi

\section{KESIMPULAN}

Berdasarkan hasil penelitian aktivitas antibakteri Staphylococcos aureus dan Salmonella thypi ekstrak metanol anggur laut (Caulerpa racemosa) maka kesimpulan yang didapatkan yaitu :

I. Ekstrak metanol anggur laut (Caulerpa racemosa) mempunyai aktivitas antibakteri terhadap Staphylococcos aureus pada konsentrasi $100 \%$ dengan respon daya hambat kuat sebesar 15,7 mm.

2. Ekstrak metanol anggur laut (Caulerpa racemosa) mempunyai aktivitas antibakteri terhadap Salmonella thypi pada konsentrasi $100 \%$ dengan respon daya hambat kuat sebesar 19,9 mm.

\section{UCAPAN TERIMA KASIH}

Terimakasih dan bersyukur atas dukungan semua pihak Institut Kesehatan Mitra Bunda yang telah menyediakan fasilitas penelitian.

\section{REFERENSI}

I. Perry, \& Potter. (20|4). fundamental keperawatan. EGC : Jakarta.

2. Candrawati, L, 2010, Uji Aktivitas Antibakteri Ekstrak Etanol Daun Krokot (Portulaca oleraceae) Terhadap Pertumbuhan Salmonella typhi Secara In 
Vitro, Skripsi, Fakultas Kedokteran, Universitas Jember.

3. Marfuah, I., Dewi, eko nurcahya, \& Rianigsih, L. (2018). Kajian Potensi Ekstrak Anggur Laut (Caulerpa Racemosa) Sebagai Antibakteri Terhadap Bakteri Escherichia Coli Dan Staphylococcus Aureus. I.

4. Febriyenti, F., Suharti, N., Lucida, H., Husni, E., \& Sedona, O. (2018). Karakterisasi dan Studi Aktivitas Antioksidan dari Ekstrak Etanol Secang (Caesalpinia sappan L). Jurnal Sains Farmasi \& Klinis, 5(I), 23

5. Depkes, RI. (2000). Parameter Standar Umum Ekstrak Tumbuhan Obat. Jakarta : Direkorat Jenderal Pengawasan Obat dan Makanan Direkorat Pengawasan Obat Tradisional, hal 3I32.

6. Harbone. (2006). Metode Fitokimia, Penentuan Cara Modern Menganalisis Tumbuhan. Institut Teknologi Bandung.

7. Abu bakar, P. M. S., \& Yamlean, P. V. Y. (2019). Uji Daya Hambat Ekstrak Rimpang Lengkuas Merah (Alpinia Purpurata K.Schum) Terhadap Pertumbuhan Bakteri Klebsiella Pneumoniae Isolat Sputum Pada Penderita Pneumonia Resisten Antibiotik Seftriakson.Pharmacon, 8(I), II-2I.

8. Muljono, P., Fatimawali, \& Manampiring, A, E. (2016). Uji aktivitas antibakteri ekstrak daun mayana jantan (Coleus atropurpureus Benth) terhadap pertumbuhan bakteri Streptococcus Sp. dan Pseudomonas Sp. E-Biomedik $(E B m), 4(I)$, I64-I 72.

9. Misna, \& Diana, K. (20/6). Akitivitas antibakteri ekstrak kulit bawang merah (Allium cepa L.) Terhadap bakteri Staphylococcus aureus. Journal of Pharmacy, 2(2), 138-144.

10. Kristanti, A. N., Aminah, N. S., Tanjung, M., \& Kurniadi, B. (2008). Buku ajar fitokimia. Surabaya, Airlangga University Press, hal 23.

II. Liu, D. Q., Mao, S. C., Zhang, H. Y., Yu, X. Q., Feng, M. T., Wang, B., Feng, L. H., \& Guo, Y. W. (20I3). Racemosins $A$ and $B$, two novel bisindole alkaloids from the green alga Caulerpa racemosa. Fitoterapia, 91, I5-20. https://doi.org/10.1016/j.fitote.2013.08.014

12. Pendit, P. A. C. D., Elok Z., dan Feronika H. S. 2016. Karakteristik Fisik-Kimia Dan Aktivitas Antibakteri Ekstrak Daun Belimbing Wuluh
(Averrhoa bilimbi L). Jurnal Pangan dan Agroindustri, 4(I) : 400-409.

13. Purwantiningsih, T. I., Yustina Y. S., dan Widodo. 2014. Aktivitas Senyawa Fenol Dalam Buah Mengkudu (Morinda citrifolia) Sebagai Antibakteri Alami Untuk Penghambatan Bakteri Penyebab Mastitis. Buletin Peternakan, 38(I).

14. Katrin, D., Idiawati N., Sitorus B. (20I5). Uji Aktivitas Antibakteri dari Ekstrak Daun Malek (Litsea graciae Vidal) Terhadap Bakteri Staphylococcus aureus dan Escherichia coli. JKK, Volume 4(I), 7-I2 ISSN 2303-I077.

I5. Hainil, S., Arbain, D., \& Putra, D. P. (20I5). Kajian Kimia Dari Fraksi Etil Asetat Kulit Batang Kayu Pahit (Picrasma Javanica Bl.). Jurnal Sains Farmasi \& Klinis, 2(I), I-7.

16. Hainil, S., Elfasyari, T Y., \& Sulistya, R.I. (202I). Identifikasi Bakteri Escherichia coli Sesu Kedelai Murni di Pasar Jodoh Kota Batam. Jurnal Surya Medika (JSM), 7(I), 25-30.

17. Mayefis, D., Hainil, S., \& Afika, N. (2020). Antibacterial And Antifungal Activity Of Sponge Extract From Natuna Water, Riau Islands. Research Journal of Pharmaceutical, Biological and Chemical Sciences. ISSN: 0975-8585. 